Teofana Dimitrova,

Ph.D., Associated Professor, Plovdiv University Paisii Hilendarski, Bulgaria

iD ORCID ID, 0000-0003-1306-185X

email: teofana.dimitrova@uni-plovdiv.bg

Trayan Yosifov,

Ph.D., Plovdiv University Paisii Hilendarski, Bulgaria

(iD) ORCID ID, 0000-0002-7761-3900

email: victory@uni-plovdiv.bg

Correspondence author: teofana.dimitrova@uni-plovdiv.bg

\title{
INNOVATION PERFORMANCE OF BIOTECHNOLOGY FIRMS IN BULGARIA: OPPORTUNITIES FOR ENHANCING
}

Abstract. This paper deals with the investigation of the possibilities to improve the innovation performance in Bulgarian biotechnology firms. The main research purpose is to analyze Bulgaria's position concerning the innovative development of bio-based production. Methodological tools of the research methods were processing quantitative data, content analysis, and comparative situational analysis in combination with dynamic graphic analysis. The results of the research showed that there is a significant deficit in Bulgaria in the innovative development of biotechnology firms. The enhancement of the innovative biotechnological state of Bulgarian firms is a matter of great importance to their successful production and market performance on both the local and international markets. A small number of firms manage to find an adequate solution to creating stable market advantages and face insurmountable difficulties in trying to make it on the global market. Furthermore, Bulgaria's membership in the EU creates additional formal demands for providing a high quality of the production process, putting the local biotechnology firms in an even more challenging position. It suggests that companies need to focus their attention on producing goods with high added value (which is the basis of innovation) and applying and perfecting successful market-oriented approaches. In that relation, the arguments were summarized for the practical benefits of designing a complete model focused on biotechnology firms' market orientation, which is of crucial importance for their long-term innovative development. The study presents an author's conceptual model for measuring innovation performance of biotechnology firms which contains three constructs: market orientation, knowledge integration orientation, $R \& D$ effectiveness. The results from the conducted research could be helpful to research and practice R\&D developers of firms with an established presence and long market history and upstart enterprises that cannot rely on income from their market activity, market or production experience.

Keywords: biotechnological innovations, business development, innovation management, innovation performance, market orientation.

Introduction. Biotechnology, nanotechnology, and information and communication technology (ICT) are considered the most influential driving forces behind the new economics of knowledge. The global challenges related to the scarceness of natural resources, climate change, population rise, pollution, and disruption of the environment through the production of large quantities of dangerous waste and residue demand a radical global change in the line of thinking which is already recognized, acknowledged and activated. Therefore, it is not surprising that over the past three decades since its introduction, biotechnologies became one of the advanced technologies that countries are investing in to achieve sustainable development in the current century. The capabilities of this knowledge are the creation of fundamental and gradual innovations, in addition to the several applications that generate wealth for

Cite as: Dimitrova, T., \& Yosifov, T. (2021). Innovation Performance of Biotechnology Firms in Bulgaria: Opportunities for Enhancing. Marketing and Management of Innovations, 2, 104-114. http://doi.org/10.21272/mmi.2021.2-09 
countries (Aghmiuni et al., 2020). The global biotechnology market has grown over the last few years, fueled by economic recovery, increased research funding, and government initiatives (Barcelos et al., 2018).

This paper focuses on the possibilities to improve innovation performance in Bulgarian biotechnology firms. During the last decade, the Bulgarian economy has achieved macroeconomic stability and growth. Various measures were implemented to enhance the environment for doing business (Angelova and Pastarmadzhieva, 2020). Furthermore, the country has a wide variety of resources which are the main raw material for bioindustry enterprises. At the same time, there is a serious deficit in terms of the scientific and research activity and the creation of partner relations among the parties building the biotechnology ecosystem (Yosifov, 2019).

Literature Review. Biotechnology, long reserved for research laboratories, is increasingly used industrially (Lalanne et al., 2021). The current thinking is that biotechnology comprises one of the essential industries in a knowledge-based economy (Kang and Park, 2012). That is because its revolutionary discoveries have to define importance in the development of life and well-being of humankind. There is vast potential in the biotechnology field, and many breakthroughs have already been achieved in healthcare, food, agricultural products, and environmental production (Sharma and Swarup, 2003).

The science of life and particularly the biotechnology industry could be defined as applying science and technology to living organisms and parts, products, and models thereof to alter living or non-living materials to produce knowledge, goods, and services (OECD, 2005). There are several classifications of biotechnologies, but perhaps the most popular is the color-code classification. Over the years, different suggestions have been made for the colors used to differentiate among the broad scope of biotechnological activities. Even Kafarski (2012) jokingly points out that some classifications use almost all hues of the rainbow. He suggests the following differentiation among the more critical biotechnological areas: green (development of agriculture), red (health preservation, medical or pharmaceutical biotechnology), white (application of biocatalysis in industrial processes), violet (patenting of inventions), yellow (health-promoting or nutraceutical one), blue (marine and fresh-water), brown (management of arid lands and deserts).

The biotechnology market is exclusively a «special case» (Aghmiuni et al., 2020) because the company's strategic decisions about how to operate within it could not be typical. Following the study (Rajamaki, 2008): 1) profound technological uncertainty is a key characteristic of biotechnology; 2) side effects emerging after the product has been in the market can cause a shutdown of an entire product line or cut down estimated market potential; 3 ) a biotechnology product's lifecycle could also face premature drop-off due to challenges originating from market uncertainties; 4) the threat of obsolescence that is high in a market where innovations are introduced at a rapid rate; 5 ) the capability of protecting intellectual property rights. Finally, these challenges make it difficult to estimate the size of a potential market. In practice, this supposes various specific business models, but there does not exist one single model for success (Konde, 2009). It is entirely valid for the companies within the industry that 'being innovative means to survive in a competitive environment. The sector is driven by strong R\&D efforts in life science that are still looking for their reward and overall acknowledgment. For instance, in the health care sector, biotech drugs, vaccines, and diagnostics contribute to improved health and quality of life. In the energy and chemical sector, biotech innovation reduces dependence on petroleum and fossil fuels and, consequently, positively impacts the environment. Biotech innovation reduces dependence on petroleum and fossil fuels (Lokko et al., 2018). Furthermore, it should be clear that the future of the modern industry is unthinkable without biotechnology and its innovations (Osmakova et al., 2018).

Innovation performance is a determinant of success and a significant factor for profit (Wahyuni and Sara, 2020). Under the innovation performance (IP), the company could create knowledge and deliver customer value through biotechnology innovation. Thus, based on previous researches (Schwartz et al., 
2011; Tung and Yu, 2016; Wahyuni and Sara, 2020; Wilson et al., 2014), it was identified five crucial components of IP such as creativity, innovation leadership, number of patents, attaining new capital, building partnerships.

Creativity is a core competence of a biotech enterprise because it could help an organization maintain its competitive advantage and ongoing innovation (Tung and $\mathrm{Yu}, 2016$ ). This term contains the idea of creating a novelty (what should be different from what is on the market) and usefulness (how could this novelty respond to customer needs) through innovation.

Innovation leadership has a significant emphasis on the improvement of innovation performance. Following the study (Tung and $Y u, 2016$ ), it stands to mention that 1) leadership is one of the most critical factors for stimulating designer thinking among employees; 2) the goal orientation could influence the behavioral strategies that people choose for pursuing their own creativity and innovation goals.

Patents are an important strategic resource and a legal safeguard to protect proprietary innovations (Renko et al., 2020). They are attractive assets for biotechnology companies because they defend themselves from unfair competition and provide the monopoly power over the usage and management of the creation (such as signing license agreements, sales, etc.). Even though patents do not offer information for the customer value of biotechnology, they are an essential indicator for its novelty and protection.

The realization of innovative projects within the biotechnology industry entails high expenditure for conducting scientific research and obtaining patent rights and the market implementation of the new products. In other words, at every stage of the project execution process in bio-industrial production, there is a dire need for regular financing of various-in-scope activities. The most frequent sources of financing innovative biotechnology projects are (Yosifov, 2020) SWORD financing, business angels financing, financing through specialized funds for risk financing.

Building partnerships for combining resources to achieve innovation is a widely used method in the biotechnology industry. These inter-organizational networks promote learning and exchange of scientific knowledge, emerging technology, specialized information, and equipment. In the innovation process, biotechnology SMEs are located at the hub of a network of upstream and downstream firms. They serve as value-adding intermediaries between upstream partners, such as universities and research institutions, and downstream partners, such as established enterprises with marketing and financial capabilities. Besides, they take on a dual role of knowledge transformation and commercialization (Kang and Park, 2012). More generally, partnerships across the board signal timely access to ideas and funds, reduced risk, and the promise of windfall gains (Gilding et al., 2020). Typical examples for establishing strategic partnerships concerning value chain development are the widely prevailing strategic alliances and clusters that shaped the biotechnology ecosystem (Hall and Bagchi-Sen, 2001; Wilson et al., 2014). The leading innovation countries also benefit from working relations between the business and scientific centers since bio-industrial companies provide occupations, income, and budget revenue. On a macroeconomic level, the bioindustry expectations would maintain their increasing importance for economic growth on a global scale in the future. However, it should be noted that the very popular «copy/paste» technique of a publicprivate partnership (PPP) model and its introduction in biotechnological innovations would not work (Vladikov and Radeva, 2016).

Methodology and research methods. This paper presents results from a conducted preliminary study which is part of the first such large-scale research dedicated to the innovative performance of the biotechnology industry in Bulgaria. The activities completed at this first stage are:

1) setting the goals and research problems;

2) formulation of hypotheses;

3) conducting literature review; 
4) consulting with subject-matter experts - representatives of academia (professors and postgraduate fellows) and managers of bio-industrial production companies;

5) secondary data collection and analysis;

6) developing a conceptual model for measuring innovation performance of biotechnology enterprises.

This study considers the opinion of various authors that such preliminary study is significant and defining for the success of the subsequent pilot testing and for conducting the main study (Smith et al., 2015). Notably, it could present adequate information about precisely defining the subject of interest and working a suitable methodology for research.

The main purpose of the current research is to analyze Bulgaria's position concerning the innovative development of bio-based production.

The research propositions are:

P1: Biotechnology companies in Bulgaria achieve a low level of innovation for the period 2015-2019.

P2: The possibilities for improving the innovation performance of Bulgarian biotechnology companies could be found by determining the factors whose influence and strength they define.

To achieve the set goal in the research, specific categories of statistical indicators are as follows: expenditures for the development of biotechnological innovation projects on the "Company» level in Bulgaria; actual expenditure realized in financing biotechnological innovations in USA and Europe through risk capital.

Based on the gathered information, comparative situational analysis in combination with dynamic graphic analysis was conducted. The data sources are Eurostat, National Statistical Institute, Ministry of Economy, National Venture Capital Association (NVCA).

Results. In effect, the traditional sources of financing do not have defining importance for the development of biotechnological innovations. The reasons for this have to be sought at the highest level of investment risk, which «cools» the interest of most conventional investors and the inability of companies to secure with finances and steady income the service of traditional bank credit. That is why for the development of innovations in Sciences of life, the main driving force is the share risk financing in its various forms, which provides regular financing and consultant support for each stage with project execution. It is necessary to point out that unlike the investment environment in the USA, the meaning of the risk capital for the development of bio-industrial production is significantly lesser in Europe. The reasons for this are various - from the stricter regulations on the environment, through the lack of a meaningful investment process directed towards financing expenditures having to do with scientific and research activity, to the less significant role of capital markets and investment banking in Europe. Unfortunately, it needs to be pointed out that the European economy cannot respond appropriately to the modern high standards for developing bio-industrial production, which is established in North America and countries such as Japan, China, South Korea. Notably, all of these countries are leaders in developing innovations in the sector of biotechnologies. That undoubtedly places the European countries predominantly in the position of users of innovative products from the global bio-industrial market.

Figure 1 shows a comparative analysis of risk share financing in the USA and Europe over 10 years directed towards project realization of bio-based industrial production. The data supports the already established reality of the trailing European economy. The rate at which it changes does not give the reasons to presume that this distance would be covered in the immediate future. 


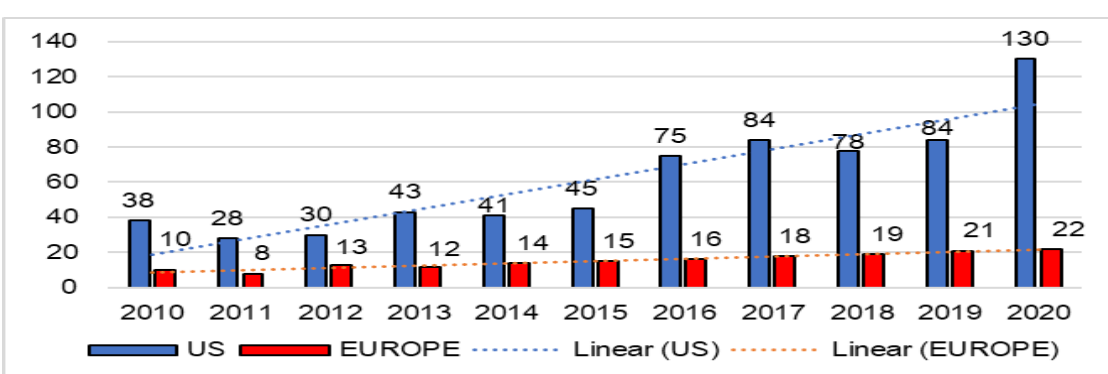

Figure 1. Size of financing of biotechnological innovations with risk capital in USA and Europe comparative characteristics, 2010-2020 (billions of dollars)

Sources: developed by the authors based on (NVCA, 2020).

At the backdrop of the trailing European economy, it is not surprising that the development of biotechnological innovation projects in Bulgaria is at a dissatisfactory level. A testament to this is the insignificant share of total annual expenditure for R\&D (below half percent of the country's GDP for 2020). Nevertheless, there is the reason for optimism having to do with the development of the «Healthcare» sector, which concentrates the main part of biotechnological expenditure for R\&D via the Ministry of Economy, along with the technical and natural sciences (Ministry of Economy, 2017, 2018; Global metrics, 2019). The research results show that for 2015-2019, biotechnology companies that realized innovations increased by 28 and reached 81 in 2019. The occupied positions in R\&D barely changed and are 581 people in 2019 , which is $1,66 \%$ of the total number of employed people in the R\&D in sector "Companies» for the same period. The average employment in a company in 2019 drops down to 7 people compared to data from 2015, which indicates the lack of favorable perspectives for the development of bio-based innovations in the country. The total turnover of innovative biotechnology companies for the same year reaches 3,4 million euros, comparable to results for 2015 , and testifies to the lack of progress in that area. Table 1 and Figure 2 give a summarized view of the data.

Table 1. Summarized data for realized biotechnological innovations in Bulgaria

\begin{tabular}{cccc}
\hline Period & Companies (number) & Employed (number) & Average employment per company (number) \\
\hline 2015 & 53 & 580 & 11 \\
2019 & 81 & 581 & 7 \\
\hline
\end{tabular}

Sources: developed by the authors based on (Ministry of Economy, 2017, 2018; Global metrics, 2019).

\section{ANNUAL TURNOVER OF BIOTECHNOLOGY COMPANIES IN BULGARIA (millions of euro)}

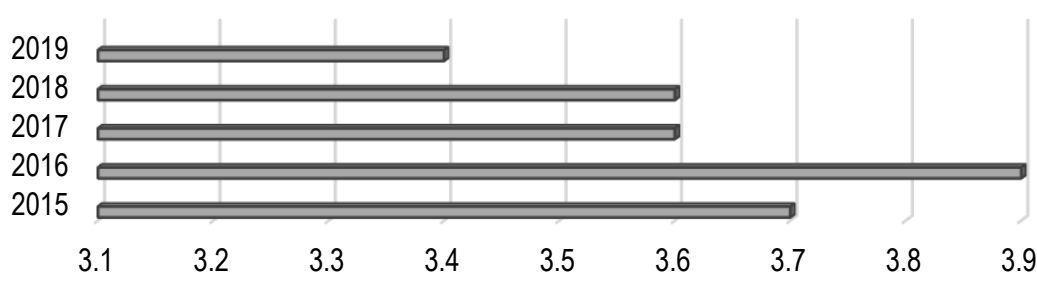

Figure 2. Turnover of biotechnology companies in Bulgaria for 2015-2019 (millions of euro) Sources: developed by the authors based on (Ministry of Economy, 2017, 2018; Global metrix, 2019). 
Despite its limited size, biotechnological production in the country encompasses a broad area of manufacturing. Due to modern technical and scientific achievements, several economic sectors improved their development, including: production of yogurt-type products (in this production lactobacilli and enzymes are used to produce foods such as yogurt, lactic butter and different types of cheese); production of brews (the main substrate used are grown barley seeds (barley malt) and the main biologic agent which perform the alcoholic fermentation are yeast cultures of genus Saccharomyces); production of wine and concentrated alcoholic beverages (the substrates used are products containing carbohydrates which along with highly productive cultures of genus Saccharomyces transform to alcohol); production of vinegar which is based on the use of alcohol-containing substrates with acetic acid bacteria acting upon them; production and use of bread yeast (which is a live microbe culture made out of fresh bread yeasts; during the production of several types of bread and similar products along with the bread yeast the following hydrolase enzymes are used: amylase, cellulase, lipase); production of bacteria-based fertilizers and bioinsecticide products. It supposes that the basis and traditions for the development of modern biotechnological production are available. Besides, what needs to be resolved is the complicated problem of building on and increasing the economy's production capacity by realizing innovations on the «company» level.

The analysis of the development of innovative biotechnological projects in Bulgaria is a serious challenge. One of the main reasons for this is that the entire scientific and research studies in the country on life sciences are extremely rare. The summarized review of the market shows that the main portion of employed people for 2019 (a total of 581 people) are in companies with an average number of 7 employees, i.e., micro- to small companies, predominantly newly-operating (Figure 3). It indicates the limitation of human resources for developing complete bio-based innovative projects and the lack of a meaningful economic capacity for attracting external financing. Furthermore, companies realizing innovative biotechnological projects have limited commercial presence in the country regarding insignificant income from sales, explaining the small average number of people employed in the science and research teams.

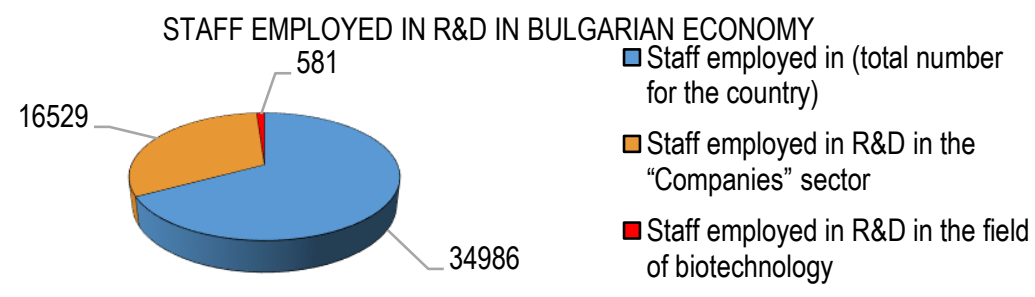

Figure 3. Number of employees in R\&D activities for the entire country in the "Companies» sector and employed in the field of biotechnological innovations for 2019

Sources: developed by the authors based on (National Statistical Institute data, 2021).

As established, there is a significant deficit in Bulgaria concerning the innovative development of biobased production, i.e., the first formulated proposition is confirmed. Thus, identifying the drivers of innovation performance in the biotechnology industry is an important part of the search and provision of opportunities for actions directed towards different areas of improvement (second proposition).

The literature review on biotechnological innovations shows a deficit of research dedicated to biotechnology innovation performance drivers. Nevertheless, some of the most significant works over the past ten years cannot be overlooked. Notably, De Luca et al. (2010) provided a test of the effect of market orientation on R\&D effectiveness and the moderating role of knowledge integration in this relationship. 
They showed that the different dimensions of market orientation have diverse impact on the R\&D effectiveness of high-technology firms in the biotechnology industry. On the other hand, Wilson et al. (2014) tested the unexplored relationship between market orientation (MO), alliance orientation (AO), and business performance (PERF) in the medical/healthcare subsector of the Canadian biotechnology industry. The research testifies to the discovery of a positive and meaningful relation between $\mathrm{MO}$ and PERF. Besides, MO's influence on PERF was found to be fully mediated by AO. Thirdly, Renko et al. (2020) investigated the role of market orientation on acquisitions. Their findings showed that a target's market orientation is an important direct driver of acquisitions and a substitutive interaction effect between market orientation and the new product development stage.

Many empirical investigations showed that strong market orientation is critical for entrepreneurs' innovations (Bozpolat and Seyhan, 2020; Dahou et al., 2017; Lewrick et al., 2011; Shaher and Ali, 2020; Zehir et al., 2019). This discovery provoked and directed the current research interest to developing a conceptual model that encompasses the exploration of relations between the constructs' market orientation and innovation performance of biotechnology companies. Here it needs to be pointed out that market orientation should not be synonymized with a marketing orientation. Even though the term market orientation dates back to the beginning of the 90 s of the previous century, marketing does not seem to be the paradigm on which market orientation definition and analysis stand. And the lack of a universally accepted marketing definition makes it difficult for scholars to define market orientation on marketing grounds (Prifti and Alimehmeti, 2017). This study believes that two constructs are similar in being a «product» of their application in the same administration philosophy. However, they are different in their measuring of structural relations. According to Kohli and Jaworski (1990), a market-oriented organization is one whose actions are consistent with the marketing concept. In other words, the marketing concept of administration plays an argument (independent variable). The market and marketing orientation, being quality characteristics of the firm, are a consequence.

There is a large variety within market orientation measures. Still, probably the most widely acknowledged is the initially established by Narver and Slater (1990) conceptualization which includes three components of market orientation: customer orientation, competitor orientation, and inter-functional coordination. Customer orientation and competitor orientation include all of the activities involved in acquiring information about current and future customers and competitors and using it within the firm. Inter-functional coordination is based on customer and competitor information. It comprises the business' coordinated efforts, typically involving more than the marketing department, to create superior value for the buyers.

This research adopts the conceptualization for market orientation from Kohli and Jaworski (1990) as a set of organizational behaviors and processes (i.e., a set of activities) related to market intelligence generation, market intelligence dissemination, and responsiveness to such intelligence across departments. Intelligence generation refers to the extent to which a firm collects primary and secondary information from the various market participants (i.e., customers, competitors, suppliers, intermediaries) and market environments (i.e., social, cultural, regulatory, and macroeconomic factors) (Matsuno et al., 2000). Intelligence dissemination refers to the ability of the company to distribute, share and discuss this information among relevant users within an organization by formal and informal means (Habryn, 2012).

Accounting for the specifics of R\&D in biotechnology companies, the constructed knowledge integration orientation (KOI) was included in the conceptual model, which refers to the inclination, disposition, and possibility of cooperation concerning creating knowledge in the area of biotechnologies (e.g., via desire for cooperation with scientific centers, universities, research institutes, hospitals, laboratories, participation in strategic alliances and/or clusters, access to specialized risk investors). For $\mathrm{KOI}$, a moderating effect in link market orientation and innovation performance is expected. 
Another component indicator whose relation to market orientation has already been empirically tested and confirmed in past researches is R\&D effectiveness (De Luca et al., 2010). Under R\&D effectiveness (RDE), the degree to which the company's objectives relate to desired R\&D outcomes was defined. For measures of RDE, it was suggested the following: the accomplishment of project milestones, quality of R\&D personnel, production of relevant scientific knowledge, rating of project benefits by customers, external peer evaluation of $R \& D, R \& D$ investment/sales, financial return, gross profit. RDE plays the role of moderator between market orientation dimensions and innovation performance within the conceptual model.

For evaluating IP, creativity, innovation leadership, amount of patents, attaining new capital, building partnerships were monitored.

Thus, Figure 4 presents the model for measuring biotechnology companies' innovation performance, which includes three constructs such as market orientation, knowledge integration orientation, and R\&D effectiveness.

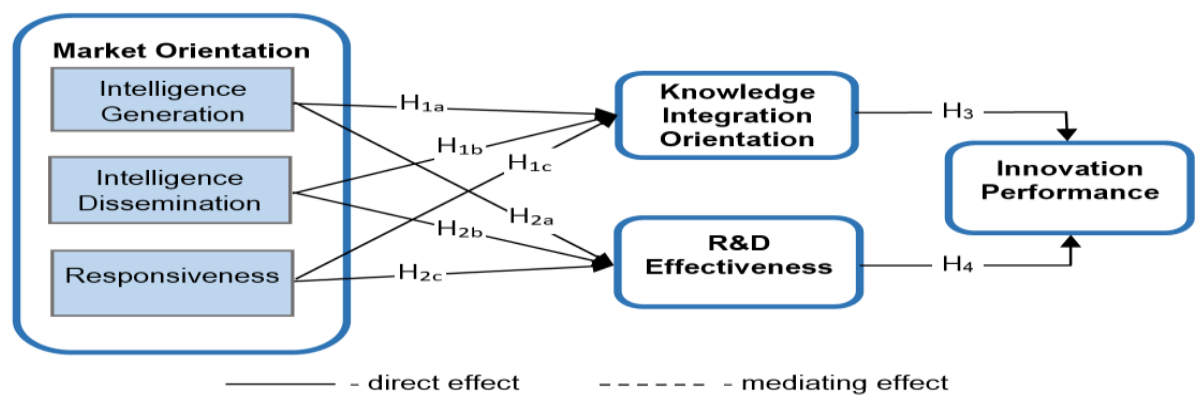

Figure 4. Conceptual measurement model for innovation performance of biotechnology

Sources: developed by the authors. enterprises

The following hypotheses were formulated:

$\mathrm{H} 1 \mathrm{a}$ : Intelligence generation is positively related to knowledge integration orientation.

$\mathrm{H} 1 \mathrm{~b}$ : Intelligence dissemination is positively related to knowledge integration orientation.

$\mathrm{H} 1 \mathrm{c}$ : Responsiveness is positively related to knowledge integration orientation.

$\mathrm{H} 2 \mathrm{a}$ : Intelligence generation is positively related to R\&D effectiveness.

$\mathrm{H} 2 \mathrm{~b}$ : Intelligence dissemination is positively related to R\&D effectiveness.

H2c: Responsiveness is positively related to R\&D effectiveness.

$\mathrm{H} 3$ : Knowledge integration orientation has a mediating effect on the relationship between innovation performance and market orientation's three components such as (a) intelligence generation, (b) intelligence dissemination, and (c) responsiveness.

H4: R\&D effectiveness has a mediating effect on the relationship between innovation performance and market orientation's three components such as (a) intelligence generation, (b) intelligence dissemination, and (c) responsiveness.

In testing hypothetical relationships, several control variables were applied: firm size (number of employees), technological region (red, green, white, blue biotechnologies), start-up, spinoff origin, number of new product development projects.

For the next pilot testing phase, the following activities are scheduled: determining the model and volume of the research, constructing the toolset of the research and testing it against a sample of biotechnology companies in Bulgaria, corrective procedures for improving the toolset, conducting an online 
questionnaire among representatives of statistical units from the defined sample (one high-ranking person from each company), performing descriptive statistics, testing the validity and reliability of the questionnaire, performing multivariate analysis, interpretation, and presentation of the results.

Conclusion. This research aimed to present a model for improving the innovative performance of companies in the country based on an analysis of the possibilities for developing biotechnology innovation companies in Bulgaria. For this, two propositions were formulated, namely: 1) biotechnology companies in Bulgaria reach a low level of innovation for the period 2015-2019; 2) possibilities for improving the innovation performance of Bulgarian biotechnology companies could be found through identifying the factors whose impact and strength define it. The results from the conducted preliminary research confirmed the formulated propositions. In this specific plan, the model is applicable for micro-, small, and medium companies and larger production companies with serious market history, established trademark, and experience in project innovation realization. Three selected constructs of the suggested model are matched entirely to the specifics of the economic environment in the country, the potential of the research centers that possess a complete main infrastructure for developing biotechnological innovations, and the importance of innovations for the economic effectiveness of the country production processes in companies. The practical applicability of the suggested model is universal, regardless of the subject chosen for the particular research. Uses from its applications can be found in scientific settings and all production companies that rely on innovation for their long-term development.

Author Contributions: conceptualization, T.D. and T. Y.; methodology, T. D. and T. Y.; formal analysis, T. Y.; investigation, T. D. and T. Y.; resources, T. D. and T. Y; data curation, T. Y; writing-original draft preparation, T. D. and T. Y.; writing-review and editing, T. D. and T. Y; visualization, T. D. and T. Y.; supervision, T. D.

Funding: This research was funded by The department for scientific and applied activities (SAA) within the Plovdiv University «Paisii Hilendarski» (the project No. FP21-FISN-004 «The Effects of Globalization: Hyperconsumption and Non-Environmentally Sustainable Behavior»).

\section{References}

Aghmiuni, S. K., Siyal, S., Wang, Q., \& Duan, Y. (2020). Assessment of factors affecting innovation policy in biotechnology. Journal of Innovation \& Knowledge, 5, pp. 179-189. [Google Scholar] [CrossRef]

Angelova, M., \& Pastarmadzhieva, D. (2020). Development of bio-based economy: Entrepreneurial endeavors and innovation across Bulgarian wine industry. Journal of International Studies, 13(2). [Google Scholar] [CrossRef]

Barcelos, M. C., Lupki, F. B., Campolina, G. A., Nelson, D. L., \& Molina, G. (2018). The colors of biotechnology: general overview and developments of white, green and blue areas. FEMS Microbiology Letters, 365(21). [Google Scholar] [CrossRef]

Bozpolat, C., \& Seyhan, H. (2020). Impact of Market Orientation on Innovation. In O. Yimaz and P. Çömez (Eds.). Innovation: Principles and Practices (pp. 269-290), Retrieved from [Link]

Dahou, K., Hacini, I., \& Bendiabdellah, A. (2017). Being Entrepreneur: Be Market Oriented to Innovate. Revue Organisation et Travail, 464(5967), 1-12. [Google Scholar]

De Luca, L. M., Verona, G., \& Vicari, S. (2010). Market orientation and R\&D effectiveness in High-Technology firms: An empirical investigation in the biotechnology industry. Journal of Product Innovation Management, 27(3), 299-320. [Google Scholar] [CrossRef]

Gilding, M., Brennecke, J., Bunton, V., Lusher, D., Molloy, P. L., \& Codoreanu, A. (2020). Network failure: Biotechnology firms, clusters and collaborations far from the world superclusters. Research Policy, 49(2), 103902. [Google Scholar] [CrossRef]

Global metrix. (2019). Analysis and evaluation of the results achieved in the implementation of the operational objectives of ISIS and the degree of progress on the strategic objective for the period from 03.11.2015 to 31.12.2018 when reporting the contribution of the instruments for implementation of ISIS. Retrieved from [Link]

Habryn, F. (2014). Customer intimacy analytics: Leveraging operational data to assess customer knowledge and relationships and to measure their business impact. KIT Scientific Publishing. [Google Scholar]

Hall, L. A., \& Bagchi-Sen, S. (2002). A study of R\&D, innovation, and business performance in the Canadian biotechnology industry. Technovation, 22(4), 231-244. [Google Scholar] [CrossRef]

Kafarski, P. (2012). Rainbow code of biotechnology. Chemik, 66(8), 811-816. [Google Scholar]

Kang, K. N., \& Park, H. (2012). Influence of government R\&D support and inter-firm collaborations on innovation in Korean biotechnology SMEs. Technovation, 32(1), 68-78. [Google Scholar] [CrossRef] 
Kohli, A. K., \& Jaworski, B. J. (1990). Market orientation: the construct, research propositions, and managerial implications. Journal of marketing, 54(2), 1-18. [Google Scholar] [CrossRef]

Konde, V. (2009). Biotechnology business models: An Indian perspective. Journal of Commercial Biotechnology, 15(3), 215226. [Google Scholar] [CrossRef]

Lalanne, L., Nyanhongo, G. S., Guebitz, G. M., \& Pellis, A. (2021). Biotechnological production and high potential of furanbased renewable monomers and polymers. Biotechnology Advances, 107707. [Google Scholar] [CrossRef]

Lewrick, M., Omar, M., \& Williams Jr, R. L. (2011). Market orientation and innovators' success: An exploration of the influence of customer and competitor orientation. Journal of technology management \& innovation, 6(3), 48-62. [Google Scholar] [CrossRef] Lokko, Y., Heijde, M., Schebesta, K., Scholtès, P., Van Montagu, M., \& Giacca, M. (2018). Biotechnology and the bioeconomyTowards inclusive and sustainable industrial development. New biotechnology, 40, 5-10. [Google Scholar] [CrossRef]

Matsuno, K., Mentzer, J. T., \& Rentz, J. O. (2000). A refinement and validation of the MARKOR scale. Journal of the Academy of Marketing Science, 28(4), 527-539. [Google Scholar] [CrossRef]

Ministry of Economy. (2017). Innovation Strategy for Smart Specialization of the Republic of Bulgaria, 2014-2020. Retrieved from [Link]

Ministry of Economy. (2018). Inovatsionna strategiya za inteligentna spetsializatsiya na Republika Bulgaria, 2014-2020. Retrieved from [Link]

Narver, J. C., \& Slater, S. F. (1990). The effect of a market orientation on business profitability. Journal of marketing, 54(4), 20-

35. [Google Scholar] [CrossRef]

National Statistical Institute. (2021). Total R\&D personnel by sectors, regions and sex. Retrieved from [Link]

NVCA. (2020). National Venture Capital Association. Retrieved from [Link]

OECD. (2005). A framework for biotechnology statistics. Retrieved from [Link]

Osmakova, A., Kirpichnikov, M., \& Popov, V. (2018). Recent biotechnology developments and trends in the Russian Federation. New biotechnology, 40, 76-81. [Google Scholar] [CrossRef]

Prifti, R., \& Alimehmeti, G. (2017). Market orientation, innovation, and firm performance-an analysis of Albanian firms. Journal of Innovation and Entrepreneurship, 6(1), 1-19. [Google Scholar] [CrossRef]

Rajamaki, H. (2008). Anticipating and managing the challenges of biotechnology marketing. Journal of Commercial Biotechnology, 14(3), 225-231. [Google Scholar] [CrossRef]

Renko, M., Yli-Renko, H., \& Denoo, L. (2020). Sold, not bought: Market orientation and technology as drivers of acquisitions of private biotechnology ventures. Journal of Business Venturing, 106022. [Google Scholar] [CrossRef]

Schwartz, L., Miller, R., Plummer, D., \& Fusfeld, A. R. (2011). Measuring the effectiveness of R\&D. Research-Technology Management, 54(5), 29-36. [Google Scholar] [CrossRef]

Shaher, A., \& Ali, K. (2020). The effect of entrepreneurial orientation and knowledge management on innovation performance: The mediation role of market orientation. Management Science Letters, 10(15), 3723-3734. [Google Scholar] [CrossRef]

Sharma, M., \& Swarup, R. (2003). The way ahead-the new technology in an old society. Biotechnology in India I, 1-48. [Google Scholar] [CrossRef]

Smith, P. G., Morrow, R. H., \& Ross, D. A. (Eds.). (2015). Field trials of health interventions: A toolbox. [Google Scholar]

Tung, F. C., \& Yu, T. W. (2016). Does innovation leadership enhance creativity in high-tech industries?. Leadership and Organization Development Journal, 37(5), 579-592. [Google Scholar] [CrossRef]

Vladikov, A., \& Radeva, E. (2016). Legal and economic design for the formation of criteria for public-private partnership / PPP I in the region of Southeast Europe. The Balkans in Transformative Security Environment, Plovdiv University Press, pp.166-170. Retrieved from [Link]

Wahyuni, N. M., \& Sara, I. M. (2020). Market Orientation and Innovation Performance: Mediating Effect of Customer Engagement in SMEs. Journal of Economics, Business, and Accountancy Ventura, 23, 1, 28-37. [CrossRef]

Wilson, G. A., Perepelkin, J., Di Zhang, D., \& Vachon, M. A. (2014). Market orientation, alliance orientation, and business performance in the biotechnology industry. Journal of Commercial Biotechnology, 20(2). [Google Scholar] [CrossRef]

Yosifov, T. (2019). Competitive advantages in the use of biotechnological innovations. Ikonomika, 21, 100-118. Retrieved from [Link]

Yosifov, T. (2020). Biotechnological innovation through equity participation. MAKROS.

Zehir, C., Karaboga, T., Karaboga, H.A., \& Uzmez, A. (2019). Market Orientation and Innovation Performance: The Mediating Role of Entrepreneurial Strategic Posture. The European Proceedings of Social \& Behavioural Sciences, 819-831. Retrieved from [Link]

Теофана Димитрова, Ph.D., Пловдівський університет «Паїсій Хілендарський», Болгарія

Траян Йосифов, Ph.D., Пловдівський університет «Паїсій Хілендарський», Болгарія

Інноваційна діяльність біотехнологічних компаній Болгарії: напрями активізації

Стаття присвячена актуальним формування інноваційного розвитку біотехнологічних компаній. Основною метою проведеного дослідження є оцінювання потенціалу інноваційного розвитку біотехнологічних компаній Болгарії. Методичним інструментарієм проведеного дослідження стали методи контент-аналізу, порівняльного, ситуаційного та графічного 
аналізів. Ідентифіковано проблеми, які перешкоджають інноваційному розвитку біотехнологічних компаній Болгарії. У роботі запропоновано концептуальну модель оцінювання інноваційного розвитку біотехнологічних компаній, яка включає три складові: ринкову орієнтацію, орієнтацію на інтеграцію знань, ефективність науково-дослідних та дослідно-конструкторських робіт. Обгрунтовано необхідність зміцнення інноваційної складової біотехнологічних компаній Болгарії для покращення виробничого процесу та посилення конкурентних переваг на місцевому та міжнародному ринках. Наголошено, що лише окремі компанії Болгарії можуть забезпечити сталі ринкові переваги та подолати бар'єри входу на міжнародний ринок біотехнологічної продукції. Зазначено, що членство Болгарії в ЄС створює додаткові вимоги щодо забезпечення високої якості виробничого процесу біотехнологічної продукції. У ході дослідження систематизовано аргументи та контраргументи щодо практичних переваг розробки комплексної ринково-орієнтованої моделі біотехнологічних компаній, що є основою довгострокового інноваційного розвитку. Дослідження емпірично підтверджує та теоретично доводить, що біотехнологічні компанії повинні забезпечити виробництво товарів з високою доданою вартістю (що є основою інновацій), вдосконалюючи та застосовуючи успішні ринково-орієнтовані підходи. Отримані результати мають практичну та теоретичну цінність, можуть бути корисними розробникам науково-дослідних та дослідно-конструкторських робіт компаній, які присутні на ринку або компаній, які зможуть увійти на ринок біотехнологічної продукції.

Ключові слова: біотехнологічні інновації, розвиток бізнесу, управління інноваціями, інноваційні показники, ринкова орієнтація. 